\title{
Flash Flood struck Dhauliganga valley on February 7, 2021: A Case study of Chamoli district of Uttarakhand Himalaya in India
}

\author{
Sushil Khanduri ${ }^{{ }^{*}}$ \\ ${ }^{1}$ Uttarakhand State Disaster Management Authority, Department of Disaster Management, Uttarakhand \\ Secretariat, 4 Subhash Road, Dehradun-248001, Uttarakhand, India
}

Received: / Accepted: March 26, 2021 / May 6, 2021

\begin{abstract}
Combining effects of prolonged rock fall, glacier avalanche, multiple damming of streams, rapid erosion of slope materials and sudden rise in temperature witnessed a flash flood situation on 7 February, 2021. Aftermath of initial incidence which was occurred in the morning 1015 hours at upper reaches of Raunthi Gadhera, within 30 minutes Rishiganga, Dhauliganga and Alaknanda rivers swelled enormously. Unprecedented discharge of the same washed off functional Rishiganga hydroelectric project of 13.2 MW capacity on Rishiganga near Rini while badly damaged under construction hydropower project of $520 \mathrm{MW}$ of National Thermal Power Corporation at Tapoban on Dhauliganga river. Except for, 5 pedestrian bridges in various places over Dhauliganga river along with one motorable RCC bridge over Rishiganga at Rini leading to Joshimath - Malari State Highway were swept away in flash flood wherein disrupted the connectivity along with other supply of 13 villages. This caused heavy damage to life and property, particularly in these hydropower project sites. As many as 204 persons went missing, of these bodies of 77 persons could be recovered along with 12 persons injured and 184 farm animals were lost in this incidence. The aim of the present research is to examine the possible causes of the rock fall and flash flood together with their destructive effects. This work also focuses on present risk scenario and suggestions for disaster risk reduction within the affected region.
\end{abstract}

Key words: Changes in river morphology; Damages; Flash flood; Higher Himalaya; Losses; Multiple damming; Rock fall

\section{Introduction}

The fragility of Higher Himalayan terrain because of freeze-thaw actions, Thrusts/Faults and earthquakes together with high relief, narrow valley, steep slopes, intense rains and increase in temperature makes this region highly prone to a number of hazards like avalanches, rock falls, debris flows, floods and flash floods etc. Because of change in weather regime, both the magnitude and frequency of flash floods and floods have increased in the same region. These events are significant both in terms of damage to infrastructure, property, and especially in

\footnotetext{
* Corresponding Author, e-mail: sushil.khanduri@gmail.com
} 
Flash Flood struck Dhauliganga valley on February 7, 2021: A Case study of Chamoli district of Uttara...

terms of human lives [1]. Furthermore, developmental activities trigger the flood and increase the flood damage in flood plains of hydrological watersheds [2].

Cloudbursts or heavy localized precipitation and ensuring flash floods and landslides are the major concern of the region [3] and these are however often attributed to climate change [4]. But the effects of global warming, and the related changes in climate, on geo-hydrological hazards like floods, landslides and droughts remain difficult to determine, and to predict [5]. Hence, there is dire need to understand the climatic variability to overcome its harmful effects on geo-environment. Between years 1970 to 2019, total of 50 known cases of cloudbursts were recorded in Uttarakhand region, of which alone 12 events have been observed in Chamoli district killing around 300 persons and damaging numbers of property and infrastructure in these incidences [6].

In June 2013, five districts namely Chamoli, Rudraprayag, Uttarkashi, Bageshwar and Pithoragarh witnessed massive devastation due to cloudburst/heavy rainfall and associated flash floods. More than 4000 persons went missing in these incidences that caused enormous loss of infrastructure and property [7]. Because of the same, major geomorphic changes have been introduced at Kedarnath in the Mandakini valley of Rudraprayag district [8] whereas in Lambagar, Govindghat, Bhuindar and Pulna in Alaknanda valley and Tharali and Narayanbagar in Pinder valley of Chamoli district [9].

Similarly, in July 2016 the Bastari village affected by cloudburst disaster incidence are traditional habitations where people had been living happily for ages. Except for heavy rains caused landslide incidences and damages in the area around Didihat and Naulra villages. As many as 22 human lives were lost in these incidences [10].

The hilly region of Uttarakhand experienced landslides and avalanches wherein the channel of streams were blocked caused extensive flooding downstream. Flooded water of the same brought down huge amount of sediments caused aggradation in many places along the course of streams. Between the years 1857 to 2018, total of 24 events of damming of streams were recorded in the same region of which alone 12 events have been observed in the Chamoli district [11]. It is evident that the damming of streams were observed due to different geomorphological and lithotectonic causes wherein some important are (i) confluence of tributaries; (2) narrow valley; (iii) Thrust/Fault and folded strata; and (iv) physical and chemical weathering in rocks. Whatever the causes of damming of streams in the region but it was observed that most of the dam breached during the monsoon season. In the year 1893, the region experienced a massive rock fall in Birahi valley which blocked the course of Birahiganga and formed a lake named as Gohna lake. Partial breach of this lake in year 1894 and ultimate breach in year 1970 (after 76 years long period) during monsoon caused enormous flooding downstream. Similarly, in the year 1968, landslide near Rini blocked Rishiganga, created a $40 \mathrm{~m}$ high dam and breached in year 1970 (after 2 years) during monsoon causing extensive damages in downstream.

The incidence of prolonged rock falls and slumping of rock-masses even during dry seasons witnessed in the Kali and Gori valleys in Pithoragarh district, imply continuing movement at present on some of the faults of the MCT zone. This is further borne out by occurrence of earthquakes all along the belt, just south of the Great Himalayan axis [12]. During nonmonsoonal period, the region has witnessed Varunavat landslide in Uttarkashi district occurred on September 23, 2003 while Ramolsari landslide in Tehri district on March 30, 2005 [13]. There however exist no record of flash floods during the non-monsoonal period. 
Flash Flood struck Dhauliganga valley on February 7, 2021: A Case study of Chamoli district of Uttara...

The state of Uttarakhand falls in Zone IV and Zone V of Earthquake Zonation Map of India [14]. However, the present devastated Chamoli district lies in Zone V. In the recent decades, the state has witnessed two major earthquakes one of 1991 Uttarkashi $(6.6 \mathrm{Mw})$ and another of 1999 Chamoli (6.8Mw) wherein respectively 768 and 106 persons lost their lives [6]. These earthquakes occurred along the MCT, which reactivated the local faults [15].

A massive rock fall along with hanging glacier which triggered in the catchment of Raunthi Gadhera, a tributary of Rishiganga on February 7, 2021 in Chamoli district of Indian subcontinent of Uttarakhand. Subsequent blockade of the course of the same and sudden breach of landslide dam and sequential damming (at confluence of Raunthi Gadhera with Rishiganga, North of Murunna and at confluence of Rishiganga with Dhauliganga river at Rini) caused massive damages and destructions in the Rishiganga, Dhauliganga and Alaknanda rivers, particularly in the area around Rini and Tapoban. It was surprising to everyone that this flash flood occurred during the winter months when the discharge of the glacier fed rivers is minimal.

According to some researchers energy generated by mass movement and as also available temperature data indicates that sudden rise in temperature facilitated fast melting of freshly accumulated snow and ice resulting in sudden breach of dam build by landslide mass in the form of flash flood. This inflicted heavy loss of life, property and infrastructure in the downstream. Because of unapproachable event site, nobody has not known the actual ground truth and that is why, it is a cause of concern for the government, meteorologists, glaciologists, geologists and other researchers around the Worldwide. In order to effort made in the area proximity to incidence site, to evaluate the causes of rock fall and flash flood along with changes in river morphology and suggested measures for disaster risk reduction in the affected areas.

\section{Materials and Methods}

\subsection{Study area}

Present study covers Dhauliganga valley that lies in Higher Himalayan region of three tectonic blocks; (i) Main Central Thrust (MCT); (ii) Vaikrita Thrust (VT), and (iii) Trans-Himadri Fault/Malari Fault and is falls in toposheet numbers 53N/10, 53N/11, 53N/13, 53N/14 and 53N/15 (Fig. 1). A massive rock fall along with glacier avalanche took place at an elevation of $3800 \mathrm{~m}$ asl to $3600 \mathrm{~m}$ asl at the base of Nanda Ghungti $(6309 \mathrm{~m})$ which is located southeast of Rini village on the left bank of Raunthi Gadhera, a major tributary of Rishiganga river in this region. Joshimath town can be approached by Rishikesh-Badrinath National Highway (NH 58) and is at a distance of $257 \mathrm{~km}$ from Rishikesh. Rishikesh is the nearest rail head while Jolly Grant is the airport. Besides, nearest airport is at Gauchar in the area.

The flash flood affected area can be approached by Joshimath - Malari state highway. The devastated area of Rini village is situated around $22 \mathrm{~km}$ upstream of Joshimath town where has confluence of Dhauliganga river with Rishiganga. There was an operational hydropower project of 13.2 MW capacity on the left bank of Rishiganga upstream of Rini. Another devastated area of Tapoban is situated around $15 \mathrm{~km}$ upstream of Joshimath town where barrage site of a hydroelectric project of $520 \mathrm{MW}$ capacity is being constructed on Dhauliganga river by National Thermal Power Corporation (NTPC). 


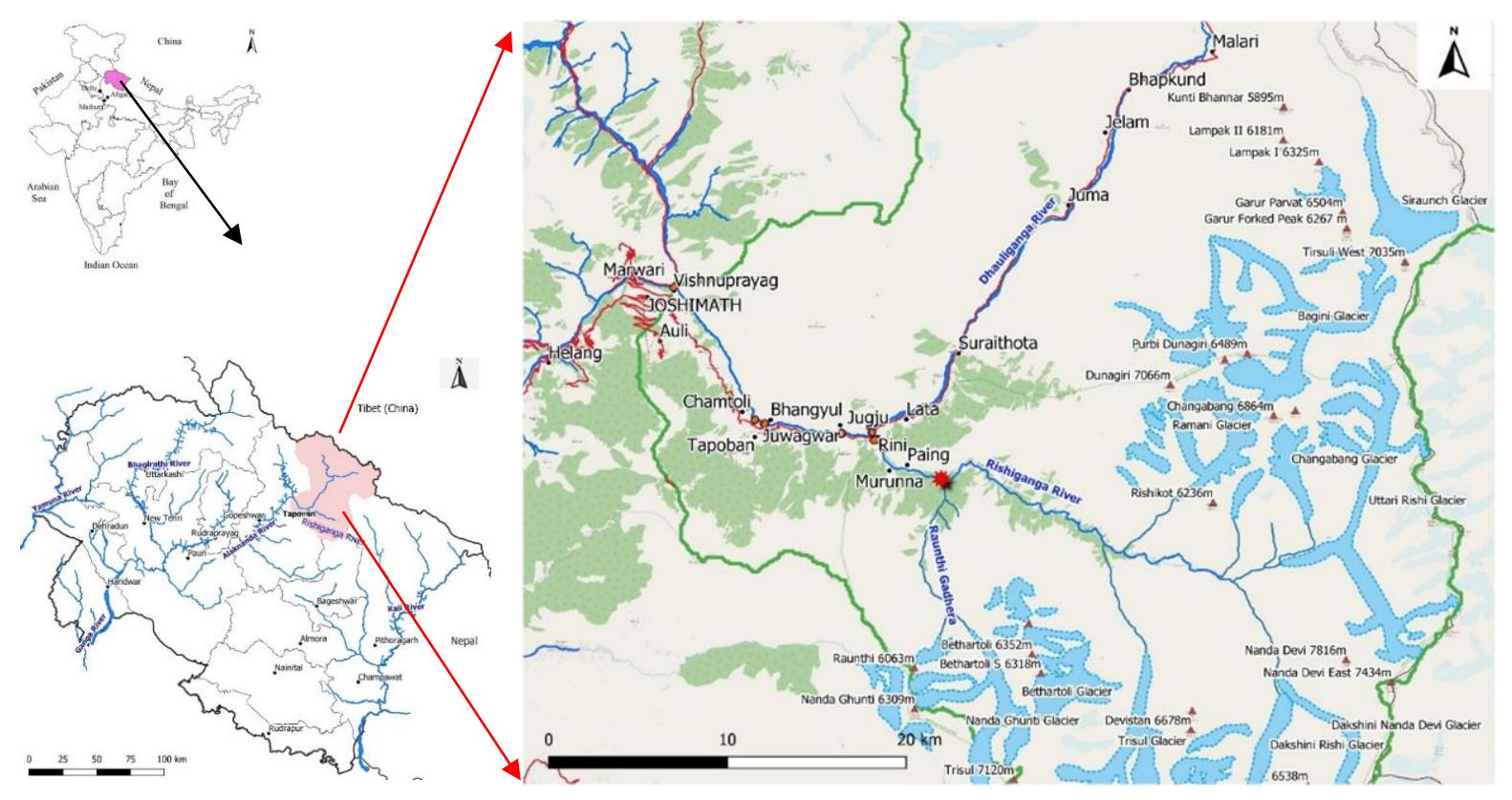

Figure 1: Location map of devastated area

\subsection{Data set and Tools}

With the help of Survey of India toposheet numbers 53N/10, 53N/11, 53N/13, 53N/14 and $53 \mathrm{~N} / 15$ on the scale of 1:50000 and handset GPS (Global Positioning System) preliminary geological assessments of the devastating flash flood in the Dhauliganga valley in Chamoli district, Uttarakhand was carried out between 19 and 28 February, 2021. Traverses were taken around the devastated areas as Rini (N 30²9'15.34" E 7941'34.91") and Tapoban (N $\left.30^{\circ} 29^{\prime} 29.76^{\prime \prime} \mathrm{E} 79^{\circ} 37^{\prime} 49.68^{\prime \prime}\right)$ to examine the geological setup and to investigate the cause of flash flood. Survey of India toposheets have also been utilize for preparation of location and other appropriate maps using Geographical Information System (GIS) software (Arc View 9.3). On the basis of information gathered, critical locations were identified for priority assessment. Attempts were also made to assess the causes of rock fall, devastating flash flood, present risk scenario and suggested measures for the safety of downstream population from the future threat.

\section{Geological setting}

The area of investigation exposes Higher Himalayan Central Crystalline Group of rocks which are thrusted over the Lesser Himalayan Garhwal Group of rocks, along a Northerly dipping Main Central Thrust (MCT) passing near Helang in Alaknanda valley. To the North of MCT, Helang Formation represents low to medium-grade rocks of greenschist facies whereas Joshimath, Suraithota and Bhapkund Formations of Vaikrita Group constitute medium to high grade rocks of amphibolite facies. These two metamorphic facies rocks are separated by Northeasterly dipping Vaikrita Thrust (VT) tracing in the proximity of Rini village in Dhauliganga valley. Another major plane of dislocation named as Trans-Himadri Fault/Malari Fault marked in Dhauliganga valley near Malari separates the Martoli Formation of Tethyan Himalayan Sequence from the Central Crystallines. Details of lithostratigraphy are given in Table 1. 
Flash Flood struck Dhauliganga valley on February 7, 2021: A Case study of Chamoli district of Uttara...

Table 1: Lithostratigraphy of the area [16-19].

\begin{tabular}{|c|c|c|}
\hline \multirow{2}{*}{$\begin{array}{l}\text { Tethyan Himalayan } \\
\text { Sequence (THS) }\end{array}$} & Martoli Formation & Greyish green slate and quartzite \\
\hline & \multicolumn{2}{|c|}{ Trans-Himadri Fault (T-HF)/Malari Fault (MF) } \\
\hline \multirow[t]{6}{*}{$\begin{array}{l}\text { Higher Himalayan } \\
\text { Crystalline Zone } \\
\text { (HHCZ) }\end{array}$} & Bhapkund Formation & $\begin{array}{l}\text { Sillimanite-garnet-biotite psammitic gneiss/ } \\
\text { schist, small tourmaline-rich leucogranite } \\
\text { lenses/ dykes and Migmatite, Malari } \\
\text { leucogranite }\end{array}$ \\
\hline & Suraithota Formation & $\begin{array}{l}\text { Kyanite-garnet-biotite schist / psammitic } \\
\text { gneiss and quartzites with thin amphibolite } \\
\text { intercalations }\end{array}$ \\
\hline & Joshimath Formation & $\begin{array}{l}\text { Garnet-biotite-muscovite schist and } \\
\text { psammitic/pelitic gneiss }\end{array}$ \\
\hline & \multicolumn{2}{|r|}{ Vaikrita Thrust (VT) } \\
\hline & Helang Foramtion & $\begin{array}{l}\text { Ganet-mica schist, augen gneisses and } \\
\text { amphibolites, quartzite }\end{array}$ \\
\hline & \multicolumn{2}{|c|}{ Main Central Thrust (MCT) } \\
\hline $\begin{array}{l}\text { Lesser Himalayan } \\
\text { Sedimentary Zone } \\
\text { (LHSZ) }\end{array}$ & \multicolumn{2}{|c|}{$\begin{array}{l}\text { Garhwal Group } \\
\text { (Meta-sedimentary and metamorphic rocks) }\end{array}$} \\
\hline
\end{tabular}

The affected area belongs to rocks of Higher Himalayan Vaikrita Group. Exposures of garnetmica schists, gneisses, amphibolites and quartzites of Joshimath Formation are observed in the area around the Rini as well as on the left bank of Rishiganga upstream of Rini. At the confluence of Rishiganga with Raunthi Gadhera, mostly exposures of quartzites of Suraithota Formation are observed on the right bank of Raunthi Gadhera as well as both the banks of Rishiganga. These rocks are medium to course grained, greyish coloured, medium to thickly foliated and slightly to moderately weathered in nature. Rocks exposed in the area are generally observed to strike NW-SE with moderate dips towards NE. Other two prominent joints were observed to dip towards $\mathrm{W}$ and NW at steep angles $\left(70^{\circ} / 270^{\circ}\right.$ and $\left.70^{\circ} / 310^{\circ}\right)$. Except for, vertical joints was observed to strike NE-SW $\left(90^{\circ} / 70^{\circ}\right)$.

\section{Geomorphology and Physiography}

Flash flood of February 7, 2021 took place in the North flowing Raunthi Gadhera that originates from the glaciers of Nanda Ghungti (6309 m). It has confluence with Rishiganga to the East of Paing and Murunna villages and maintains a tectonically controlled NW-SE course that originates from the glaciers of Nanda Devi massif. Just upstream of confluence of Rishiganga with Raunthi Gadhera area, the Raunthi Gadhera flows along the strike of exposed quartzites whereas Rishiganga flows across the strike of the same rocks. To the downstream of confluence of the same, almost Rishiganga flows along the strike of in-situ rocks. It meets with Southwest flowing Dhauliganga river at Rini village that originates in the proximity of Niti pass. From Rini to Tapoban Dhauliganga river maintains a tectonically controlled E-W course and thereafter flows from NW-SE to meet Alaknanda river at Vishnuprayag. 
Flash Flood struck Dhauliganga valley on February 7, 2021: A Case study of Chamoli district of Uttara...

Physiographically, the Rishiganga valley represents high rugged mountainous topography with high relative relief that are intervened by narrow valleys. To the South of Rini village, the valley is relatively narrow till Tapoban. Around $2 \mathrm{~km}$ upstream of Tapoban a hot water spring is located on the left bank of Dhauliganga river. Relatively wide valley in Tapoban thereafter narrow valley is observed till Vishnuprayag. Some of the high ridges and peaks of the Rishiganga are Hanuman (6,070 m), Trisul (7,045 m), Sunderdhunga Khal (6,350 m), Nanda Devi $(7817 \mathrm{~m})$ are the well-known peak in the region. The relief in the area is highly variable ranging from $1450 \mathrm{~m}$ asl at Vishnuprayag to $7817 \mathrm{~m}$ asl at Nanda Devi peak. To the downstream of villages Rini and Jugju, villages like Saldhar, Chanchri, Suhhain, Ringi and Tapoban are situated on the left bank of Dhauliganga river while villages like Juwagwar and Bhangyul are situated on the right bank. The hills on the right bank of the Dhauliganga river are observed to form high rocky surfaces in the same region.

\subsection{Changes in river morphology}

The devastating flash flood of February 7, 2021 made significant changes in the river morphology around the confluence of Raunthi Gadhera and Rishiganga. Between 9 and 11 February, 2021 the course of Rishiganga stream was permanently blocked by the debris brought down by the Raunthi Gadhera after breaching of landslide dam. Flooded water saturated debris with boulders and ice blocks of Raunthi Gadhera directly hit the valley wall which back flowed upstream along the Rishiganga dumped a huge sediments and created an artificial lake (Fig. 2a). Based on satellite imageries first by Uttarakhand Space Application Centre (USAC) on February 9, 2021 and later by Indian Institute of Remote Sensing (IIRS) were provided the information of a lake formed along the course of Rishiganga. The same was confirmed by the reconnaissance teams on February 11, 2021. As observed on February 11, 2021 water was not draining out of this lake. The Rishiganga was curved out channel from the center of the lake through which water is continuously draining out on February 12, 2021.

The lake area can be approached from both Paing and Murunna villages which are situated on the right and left bank of Rishiganga respectively. It is placed along Rishiganga about $500 \mathrm{~m}$ upstream of the confluence of Raunthi Gadhera with Rishiganga at an altitude of $2389 \mathrm{~m}$ asl having embankment of approximately $100 \mathrm{~m}$ and visually estimated linear length of around 500 $\mathrm{m}$ (Fig. 2a). It was observed that both the sides exposures of thickly to medium foliated, moderately jointed and slightly to moderately weathered quartzites that of Suraithota Formation of Vaikrita Group of rocks having with vertical cliffs. The muddy debris is to be observed on the both banks of Raunthi Gadhera whereas the Rishiganga was completely covered with huge muddy debris till lake.

It was also observed that the Rishiganga curved out around $8 \mathrm{~m}$ wide channel by the erosion of the natural embankment in the center portion till dated February 19, 2021. As directed to personnel of ITBP and SDRF, physically widen the channel and cleared of obstructions of logs (Fig. 2b). The channel was thus widened up to $20 \mathrm{~m}$ between February 22 and March 2, 2021 to ensure proper draining out water from the lake. Just upstream to confluence of Rishiganga with Raunthi Gadhera, huge slope materials was eroded on the left bank of Raunthi Gadhera while thick pile of sediments was deposited on the right bank of the same because of the flooding (Fig. 2c). This sediments comprising of a mixure of ice blocks, rock fragments, morainic material and boulders of quartzite, granitic gneiss and mica schist with silty-clayey matrix (Fig. 2d).

To the downstream of confluence, slope materials which was laid over valley side dipping rocks on the left bank of Rishiganga was badly eroded till North of Murunna village and pedestrian 
Flash Flood struck Dhauliganga valley on February 7, 2021: A Case study of Chamoli district of Uttara...

route was also completely washed away which was located on the same materials (Fig. 2e). Thereafter, debris cone and old landslide mass were also badly eroded on the right bank of Rishiganga up to confluence of Rishiganga with Dhauliganga at Rini (Fig. 2f).
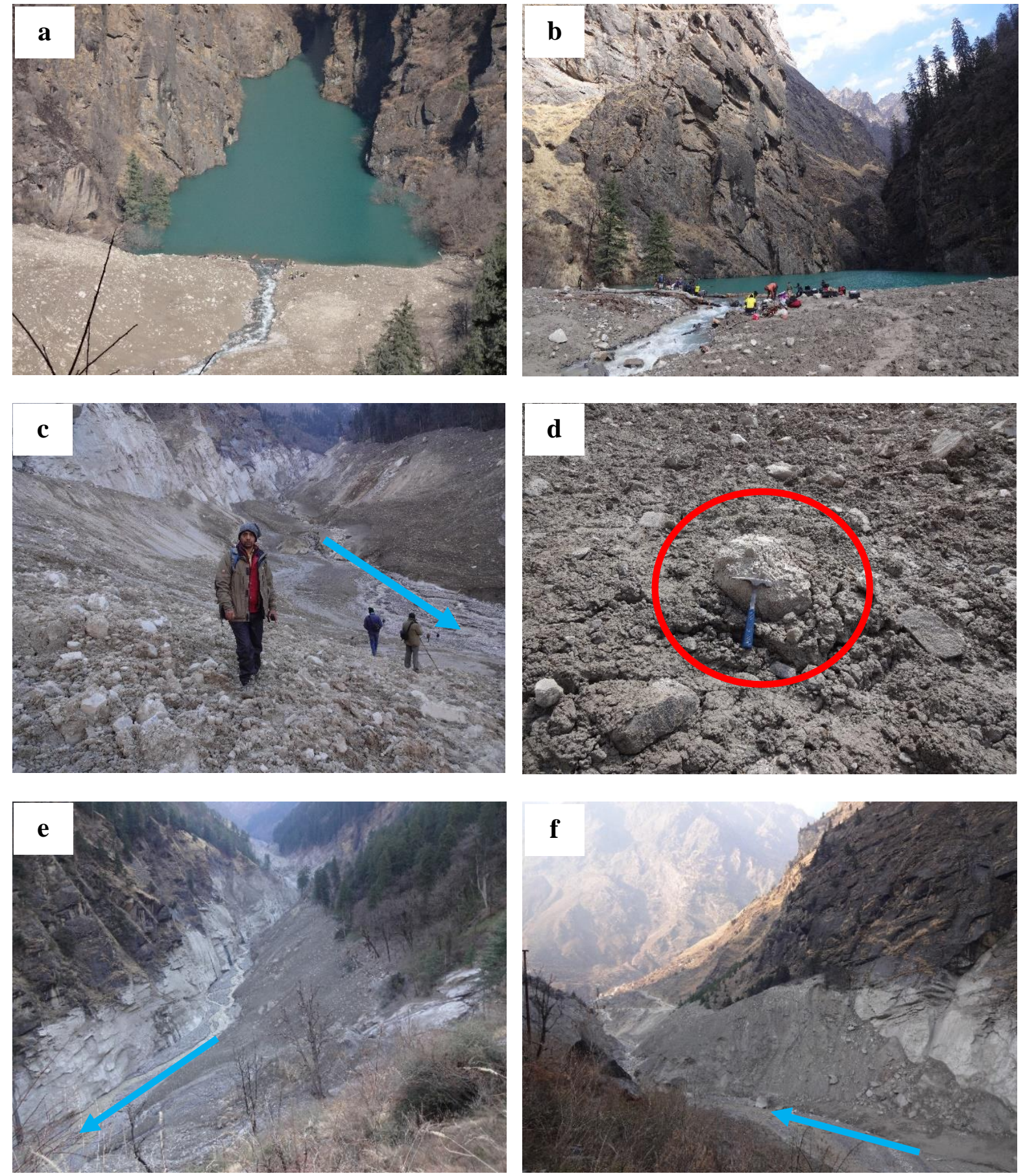

Figure 2: Changes in river morphology on the aftermath of flash flood; (a) lake formation over Rishiganga; (b) physically widen the channel and cleared of obstructions of logs; (c) eroded left bank while aggradation on the right bank of Raunthi Gadhera; (d) ice block observed in the transported debris materials; (e) badly eroded slope materials on the left bank of Rishiganga river; and (f) eroded debris cone and old landslide mass on the right bank of Rishiganga at Rini 
Flash Flood struck Dhauliganga valley on February 7, 2021: A Case study of Chamoli district of Uttara...

A huge amount of sediments of fluvio-glacial, slide mass and eroded slopes were deposited all along the course of Rishiganga, Dhauliganga and Alaknanda by ensuing floodwaters. As recorded by the gauging station of Central Water Commission (CWC) at Marwari, the discharge of Alaknanda river at 1100 hrs on February 7, 2021 reached 1,670 cumecs as against normal discharge of around 41 cumecs at $1030 \mathrm{hrs}$. CWC was also assessed that increase of $3.09 \mathrm{~m}$ in the river bed level of the Alaknanda river at Marwari on February 10, 2021. The sediment thickness is observed to reach around $12 \mathrm{~m}$ at the under construction barrage site at Tapoban whereas around $2-4 \mathrm{~m}$ in the area around Rini.

\subsection{Losses and damages}

As many as 204 persons went missing while 12 persons injured in the flash flood incidence and except for 9 local inhabitants of these 5 of Rini, 2 of Tapoban and 2 of Ringi villages and 2 Police personnel others were from amongst those engaged by the hydropower projects that were devastated in the incidence. Out of total, 77 bodies could be recovered while 184 farm animals were lost in this incidence (Data source: State Emergency Operations Centre (SEOC), Uttarakhand). According to Hydroelectric project Authority, about 30-35 persons were reportedly working in a tunnel that was chocked with silt and debris transporting by flooded water of Dhauliganga river. Total of 6 bridges were swept away by the floodwaters of which 5 pedestrian bridges which were located on the Dhauliganga river at Rini, Bhangyul, Juwagwad, Tapoban and Vishnuprayag while one motorable RCC bridge over Rishiganga river on Joshimath - Malari State Highway at Rini in which disrupted connectivity for the residents of 13 villages (Fig. 3 ).

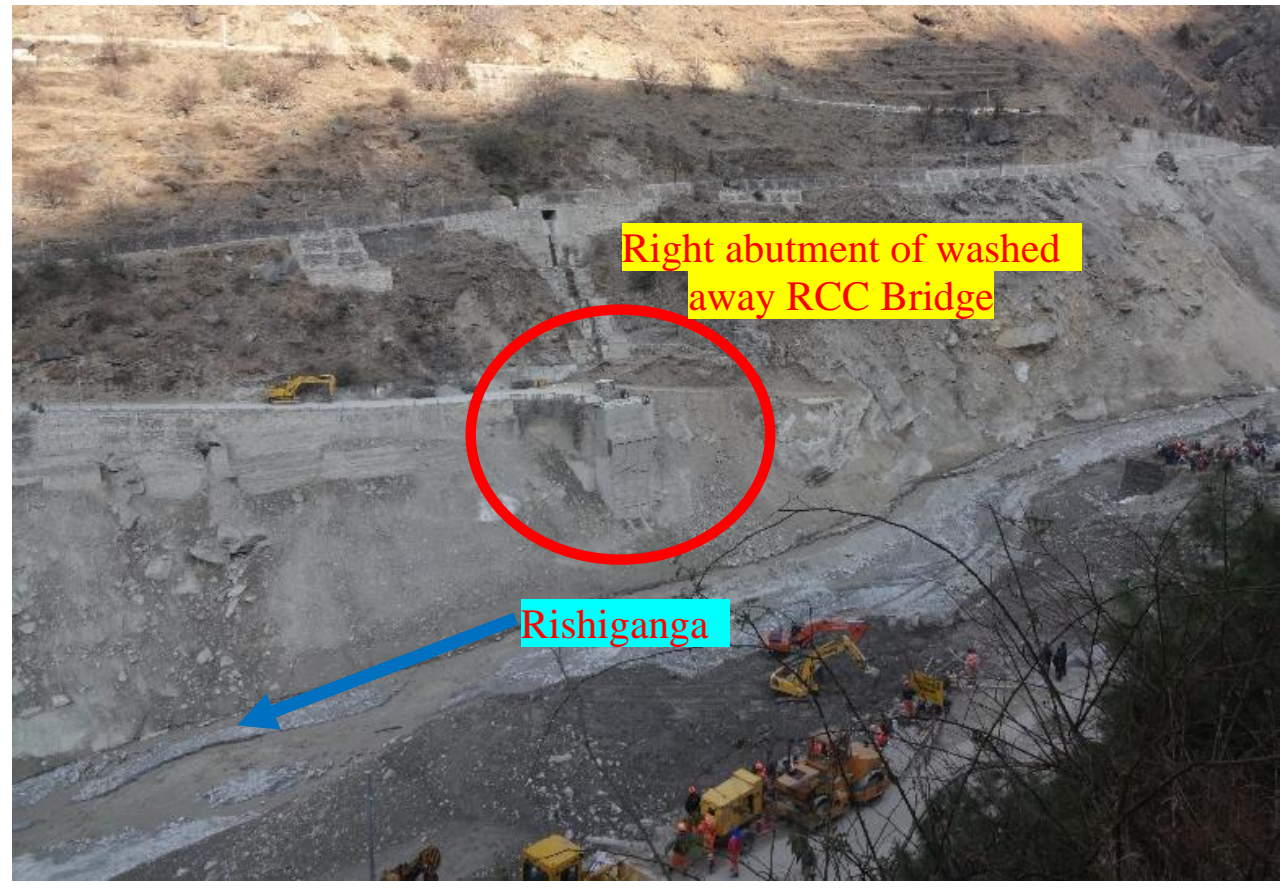

Figure 3: Washed away a motorable RCC bridge over Rishiganga river on Joshimath Malari State Highway at Rini

The flash flood of Rishiganga resulted in swiping away of an operational hydropower project of 13.2 MW capacity on Rishiganga upstream of Rini (Fig. 4a). To the downstream, flooded water of Rishiganga and Dhauliganga river severe damage to another under construction hydropower project of $520 \mathrm{MW}$ of National Thermal Power Corporation (NTPC) at Tapoban on Dhauliganga river (Fig. 4b). 

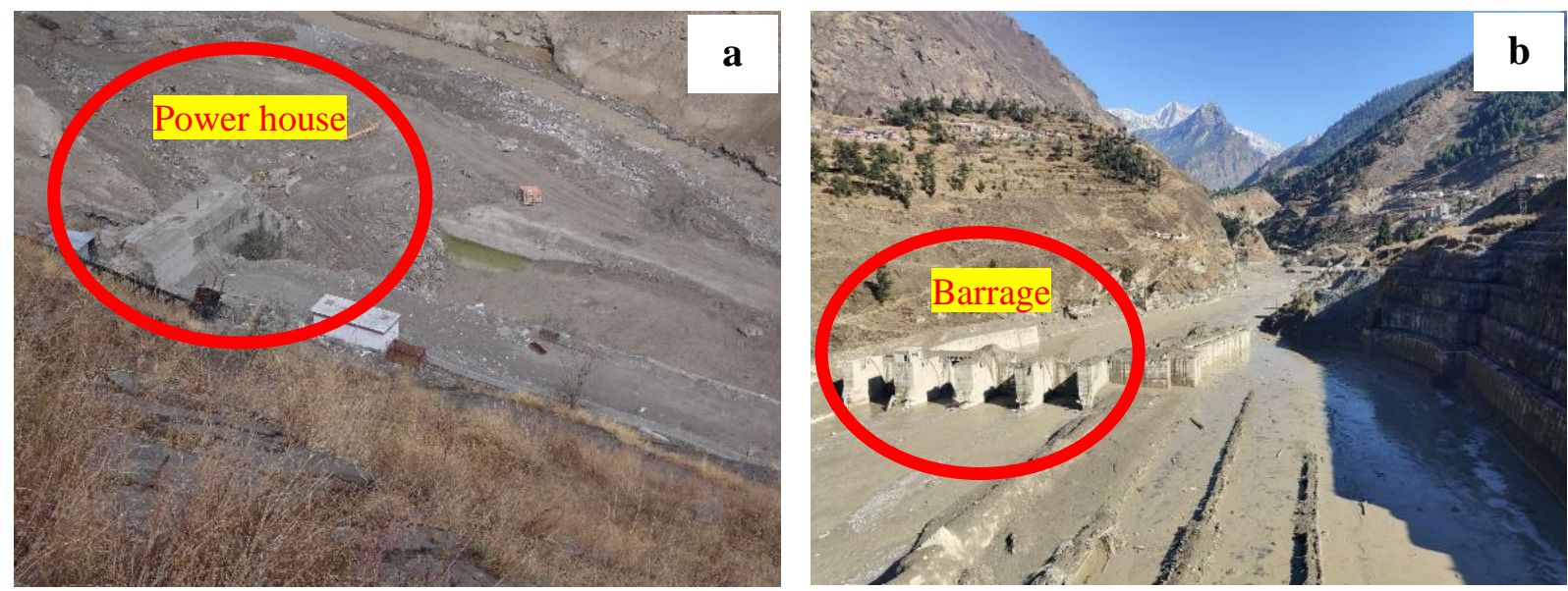

Figure 4: The devastated hydropower projects; (a) washed away power house of Rishiganga hydropower project upstream of Rini; and (b) severally damaged barrage site of TapobanVishnugad hydropower project at Tapoban

\subsection{Causes of rock fall and devastating flash flood}

Initial observation taken from the satellite imageries of Planet Lab, energy generated by the impact of free fall of huge rock mass along with hanging glacier over almost $1,800 \mathrm{~m}$ was held responsible for quickly melting snow and ice available in the area and initiating a debris flow that rushed downslope [20]. This energy is converted to kinetic energy during the fall and dissipated as enough heat to melt $2.7 * 10^{6} \mathrm{~m}^{3}$ of ice. Considering that not all the mass was converted into energy during the fall, this number is likely a lot lower. For a large co-seismic event, fluidization can also happen simply form a very large impact on present ice, which possibly happened in this case [21].

However, the region experienced precipitation on February 4 and 5, 2021 and snow fall occurred in the high altitude region of Dauliganga valley. It is evident from the Tapoban and Auli which are located at an altitudes of $2000 \mathrm{~m}$ asl and $2600 \mathrm{~m}$ asl respectively. Between 6 and 7 February, 2021 Tapoban experienced $2.8^{\circ} \mathrm{C}$ and $5.4^{\circ} \mathrm{C}$ whereas Auli $6.0^{\circ} \mathrm{C}$ and $9.6^{\circ} \mathrm{C}$ respectively in minimum and maximum temperature (Data Source: Uttarakhand State Disaster Management Authority). But it was not significant to make the situation worst, because of ice would have taken longer time than snow to melt, so this could not be the only reason for flash flood.

It is interesting to note that the Vaikrita Thrust (VT) is a major tectonic discontinuity extending to the Dhauliganga, Rishiganga and Raunthi Gadhera where the same are tectonically controlled by the VT. The Joshimath area has been intermittently sinking over a long belt for quite many decades owing to the activeness of the Vaikrita Thrust that passes by [12]. VT is separating the low-medium grade Helang Formation from the overlying medium-high grade Joshimath and Suraithota Formations in the affected area. A massive rock fall was triggered at the base of Nanda Ghungti on the left bank of Raunthi Gadhera that was observed in the close vicinity of NW-SE trending VT which activated the same. Weakening of the rocks in the affected area because of the same and this is one of the manifestations of the presence of this Thrust. Additionally, frost action and weathering could also be one of the most important factors in disintegrating the rocks in the affected area. The effect of frost action is observed to be dominant 
Flash Flood struck Dhauliganga valley on February 7, 2021: A Case study of Chamoli district of Uttara...

resulting in moisture and melting ice facilitate rock fall.

Field investigations carried out in the area aftermath of the devastating flash flood between 19 and 28 February, 2021 to reconstruct the sequence of events leading to Dhauliganga flash flood of February 7, 2021. Multiple temporary damming in the course of streams added the discharge and increased velocity of water saturated bouldary debris at many places. Brief description of the damming along the streams are given in the sections below.

A massive rock fall along with hanging glacier avalanche took place during the winter on February 7, 2021 when the discharge of glacier fed rivers is minimum. The affected area however witnessed precipitation on February 4 and 5, 2021 with experienced snowfall in the higher reaches. Subsequent damming and sudden breach of the same caused flash flood in the Raunthi Gadhera which gushing down wherein thick overburden covers was badly eroded on the left bank of Raunthi Gadhera. At the confluence of Raunthi Gadhera and Rishiganga (Fig. 5), flooded water saturated bouldary debris of Raunthi Gadhera directly hit the valley wall and damming the same place for a while wherein back flowed of sediment leaden discharge along the course of Rishiganga up to $500 \mathrm{~m}$. Increasing hydrostatic pressure result in this temporary dam was breached and to left behind a huge sediments along with boulders and ice blocks over the course of the Rishiganga and created an artificial barrier. This completely blocked the course of Rishiganga and after filling of water left behind the same materials formed a lake. This has totally changed the river morphology of the Rishiganga valley.

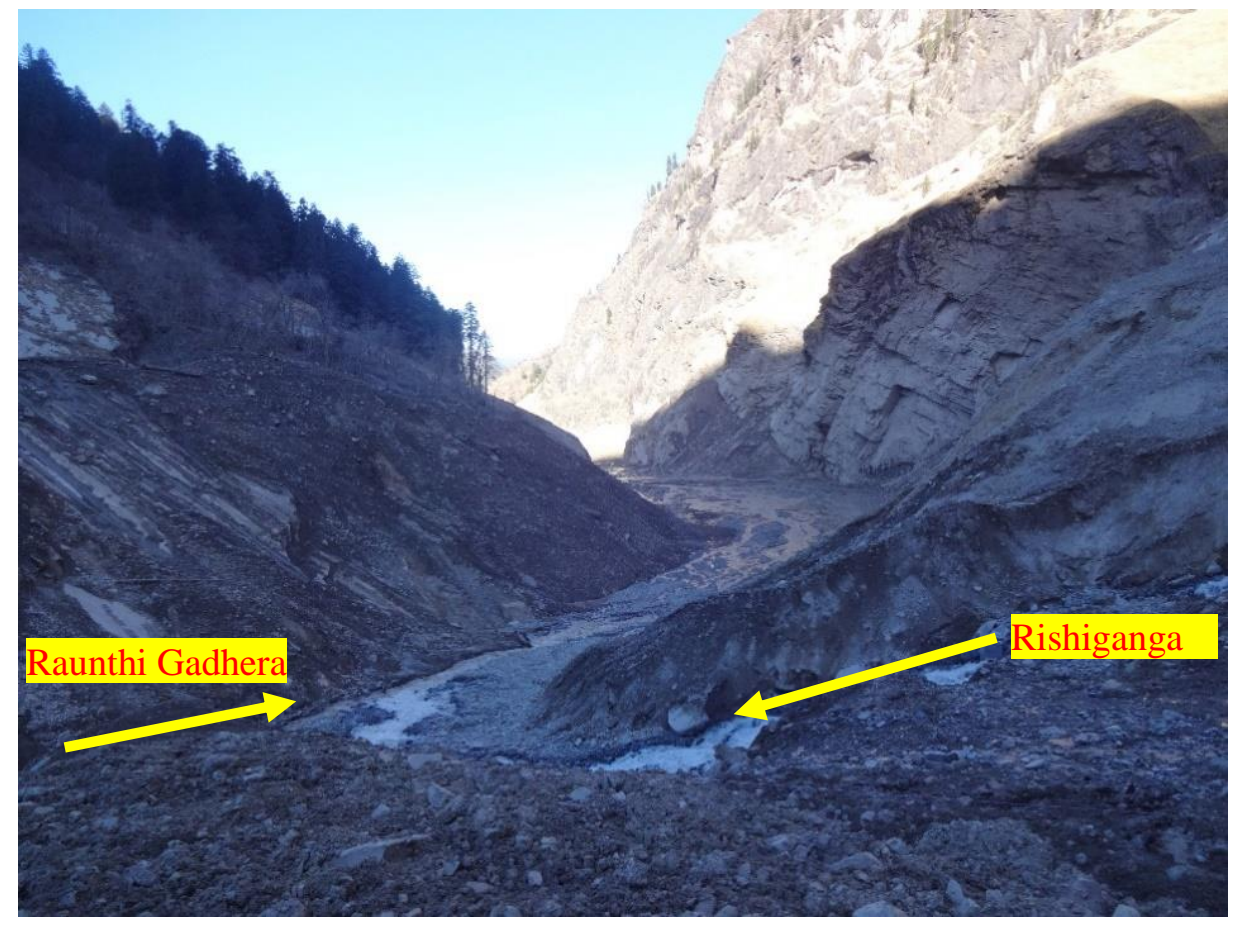

Figure 5: At the confluence of Raunthi Gadhera with Rishiganga where key damming was observed

Another intermittent ponding was observed in the North of Murunna village wherein suddenly narrow valley came across. Because of erosion of a huge overburden mass on the left bank of Rishiganga, there was enough space for accumulating water. In this area the valley walls was showing water mark which was observed up to $50 \mathrm{~m}$ height (Fig. 6a). After adding discharge result in increasing hydrostatic pressure, sudden release of the flooded water swept away operational Rishiganga Hydroelectric project of 13.2 MW capacity along with working 
Flash Flood struck Dhauliganga valley on February 7, 2021: A Case study of Chamoli district of Uttara...

personals in its. At the confluence of Rishiganga and Dhauliganga river, intermittent ponding was also observed resulting into temporary ponding along the course of the Dhauliganga river up to $1.5 \mathrm{~km}$ (Fig. 6b). Sudden release of a huge volume of water saturated debris of both the rivers caused massive devastation in the downstream. Major destruction have however occurred at Tapoban where Tapoban-Vishnugad barrage of $520 \mathrm{MW}$ was being under construction along with working personals. The intake tunnel was chocked with muddy debris where around 30 35 personals were working.
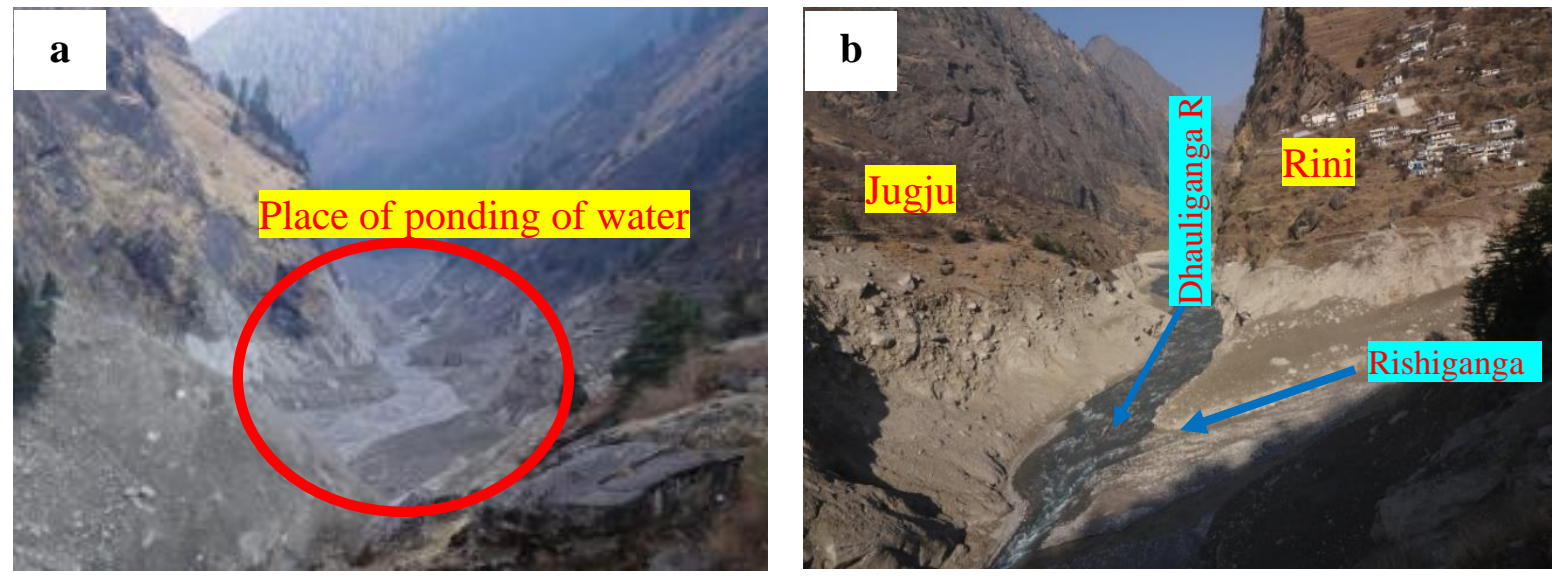

Figure 6. Intermittent ponding of streams; (a) Rishiganga to the $\mathrm{N}$ of Murunna village and (b) Dhauliganga river near its confluence with Rishiganga

It is important to note that just upstream to confluence of Raunthi Gadhera and Rishiganga, occurrence of lacustrine deposits that consist a layers of sand and pebbles on the right bank of Raunthi Gadhera which was indicating evidence of paleo lake in the same region. These deposits has now been mostly eroded in the flash flood of Raunthi Gadhera (Fig. 7). In the earlier, floods in the Rishiganga created a $40 \mathrm{~m}$ high blockade near village Rini which was formed a lake. This lake was silted up by May 1970 and eventually breached in July 1970 [11].

\section{Results and discussion}

Evolutionary history, geo-tectonic set up and change in weather regime in the Higher Himalayan terrain makes the region highly susceptible to a number of natural hazards. The region however falls in the high seismic zone. None occurrence of great earthquake $(\mathrm{Mw}>8)$ for a long period further enhances seismic risk in the region. Various anthropogenic activities for infrastructure development further aggravate the problems. Every year, the same region faces massive losses in terms of human lives, infrastructure and property due to cloudbursts, landslides, avalanches, glacial lake outburst floods (GLOFs), floods and flash floods events, particularly during monsoon season.

In the past decades, the region was hit hard by devastated flash floods in years 1970 and 2013 that caused the massive losses of human lives, property and infrastructure. In these also disrupted transport, communication, electricity and water supply facilities of the many areas for the long period. It is therefore important to plan risk assessment, better management and early warning to avoid human and other losses by these natural hazards. In case of floods and flash floods prone and inundated areas, the recent modelling technology and GIS tool should be utilized for better planning and to avoid the future threat. 


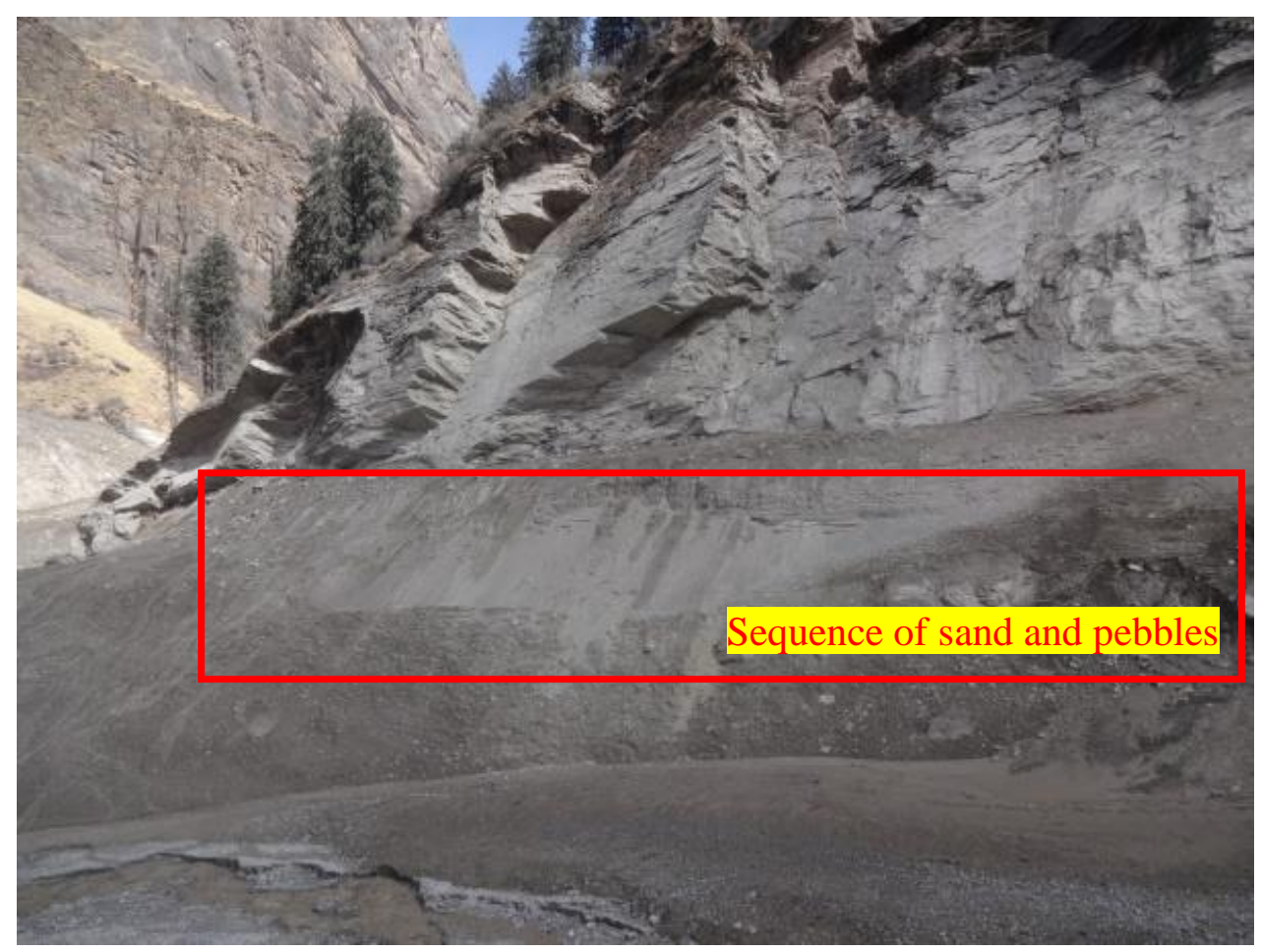

Figure 7. Lacustrine deposits on the right bank of Raunthi Gadhera near its confluence with Rishiganga

Presently, a massive rock fall along with hanging glacier that triggered on February 7, 2021 was concentrated in specific area that was associated with geomorphology and lithology. The rock fall has its origin from the base of Nanda Ghungti at an elevation of $5800 \mathrm{~m}$ asl having with steep rock slopes which sliding down along the foliation plane. Some researchers have suggested that during the 2016 cracks was observed at the base of Nanda Ghungti which was the initial cause of the rock fall. It was also noticed that rock fall area lies in the close proximity to major tectonic discontinuity named as Vaikrita Thrust which activated the same. Additionally, frost action and weathering could also be one of the most important factors in disintegrating the rocks. Among these are responsible for triggering rock fall in the affected area.

The rock fall along with a huge ice chunk blocked the course of Raunthi Gadhera at an altitude of $3600 \mathrm{~m}$ asl creating a natural dam and left behind the same huge volume of water impoundment. Because of increasing hydrostatic pressure, sudden breach of the same caused initiation of flash flood. Another, key damming was observed at the confluence of Raunthi Gadhera with Rishiganga where indication of paleo lake was observed. Additionally, intermittent ponding North of Murunna village and at the confluence of Rishiganga with Dhauliganga river at Rini were also observed. Indication of previous damming of Rishiganga near Rini was documented as well. Among these added water saturated debris with boulders gushing down with fast pace ruined and washed away everything which came in their ways.

The flash flood of Rishiganga resulted in swiping away of an operational hydropower project of 13.2 MW capacity on Rishiganga upstream of Rini whereas severe damage to another under construction hydropower project of $520 \mathrm{MW}$ of NTPC at Tapoban on Dhauliganga river. These caused 204 persons went missing of these 77 bodies could be recovered while 12 persons injured and 184 farm animals were lost in the flash flood incidence. Swiping away one 
Flash Flood struck Dhauliganga valley on February 7, 2021: A Case study of Chamoli district of Uttara...

motorable RCC bridge over Rishiganga on Joshimath - Malari State Highway at Rini along with 5 pedestrian bridges in different places along the Dhauliganga river. These resulted in inhabitants of 13 villages cut off from the road head.

The devastating flash flood of February 7, 2021 made significant changes in the river morphology around the confluence of Raunthi Gadhera and Rishiganga. Between 9 and 11 February, 2021 the course of Rishiganga stream was permanently blocked by the debris brought down by the Raunthi Gadhera after the landslide lake outburst flood (LLOF). Left behind the dumping of sediments, a huge volume of water impoundment that formed an artificial lake. Presently, this lake is draining out from the center portion but possibility of breaching of this lake in near future cannot be ruled out. As a precaution, regular monitoring of the discharge and early warning system for flood forecast should be required in the area for safety of the downstream population.

It was observed during field investigations that by and large traditional habitation in the entire affected region remained unaffected during the devastating flash flood of February 7, 2021 in the Dhauliganga valley. Keeping in these view, there is needs to promote the local inhabitants of the area to construct houses in traditional manner. This practice will reduce the losses and damages from the threat of future deluge.

\section{Conclusions}

On the basis of study carried out in the area, it is suggested that a massive rock fall along with glacier avalanche, multiple temporary damming of streams witnessed a flash flood situation on February 7, 2021. Due to the same phenomena, abnormal rise in water along with huge volume of debris materials and detached rocks that gushing down through the courses of the Raunthi Gadhera, Rishiganga and Dhauliganga river resulting in widespread damages, particularly in the area around Rini and Tapoban. These caused 204 persons went missing while 12 persons injured and 184 farm animals were lost in this incidence along with washed away 2 hydroelectric projects, 5 pedestrian bridges and 1 motorable RCC bridge.

Most of the habitations in the affected region has been situated on middle hill slopes and far away from the river bed. Because of the same, no damages however occurred in these during the flash flood. In view of vulnerability to flash flood, any kind of encroachment along the river bed should be prohibited in the future.

Presently, an artificial lake which formed over Rishiganga is needs detailed geomorphological evaluation as this is problematic during monsoon when it will contribute significant discharge and increasing hydrostatic pressure. Due to this, the situation of flash flood can occur again in the downstream. However, its effects can be reduced by estimating regular discharge and installing early warning system for flood forecast in the affected area.

In view of vulnerability to flash flood, flood in the region, DEM-based approaches for the delineation of flood-prone areas in an ungauged basins [1] and the recent modelling technology for determination of flood-prone and flood inundation areas [2] can be extremely useful. The same would help in taking safeguard against life and property losses in the region.

\section{Acknowledgements}

The Author acknowledge guidance and support from Secretary, Shri S. A. Murugesan, Disaster 
Flash Flood struck Dhauliganga valley on February 7, 2021: A Case study of Chamoli district of Uttara...

Management and Rehabilitation, Government of Uttarakhand. I am grateful to Dr. Piyoosh Rautela, Executive Director, Uttarakhand State Disaster Management Authority (USDMA), Department of Disaster Management, Government of Uttarakhand for his valuable guidance and comments have helped in bringing manuscript in this shape. Mrs. Surabhi Kundalia, GIS Expert is thanked for help in preparing location map. Colleagues at USDMA are thanked for suggestions and encouragement. I thank all the anonymous referees for their valuable and constructive comments and suggestions to improve the manuscript significantly.

Disclosure statement. The author declares that he has no conflict of interest.

\section{References}

[1] C. Samela, S. Manfreda, F. D. Paola, M. Giugni, A. Sole and M. Fiorentino, "DEM-based approaches for the delineation of flood-prone areas in an ungauged basin in Africa," Journal of Hydrologic Engineering, pp. 1-10, 2015.

[2] H. Aksoy, V.S.O. Kirca, H. I. Burgan and D. Kellecioglu, "Hydrological and hydraulic models for determination of flood-prone and flood inundation areas," The $7^{\text {th }}$ International Water Resources Management Conference of ICWRS, 18-20 May 2016, 373, pp. 137-141, Proceedings of the International Association of Hydrological Sciences (IAHS), Bochum, Germany, 2016.

[3] Sushil Khanduri, "Natural Hazards in the township of Nainital, Uttarakhand in India," International Journal of Engineering Applied Sciences and Technology, Vol. 3, Issue 12, pp. 42-49, 2019.

[4] J. Xu, R. E. Grumbine, A. Shrestha, M. Eriksson, X. Yang, Y. Wang and A. Wilkes, "The melting Himalayas: Cascading effects of climate change on water, biodiversity, and livelihoods," Conservation Biology, Vol. 23, pp. 520-530, 2009.

[5] S. L. Gariano and F. Guzzettai, "Landslides in a changing climate," Earth-Science Reviews, 162, pp. 227-252, 2016.

[6] Sushil Khanduri, "Cloudbursts Over Indian Sub-continent of Uttarakhand Himalaya: A Traditional Habitation Input from Bansoli, District-Chamoli, India," International Journal of Earth Sciences Knowledge and Applications, Vol. 2, pp. 48-63, 2020.

[7] Piyoosh Rautela, "Lessons learnt from the deluge of Kedarnath, Uttarakhand, India," Asian Journal of Environment and Disaster Management, Vol. 5, pp. 167 - 75, 2013.

[8] S. Khanduri, K. S. Sajwan, A. Rawat, C. Dhyani, S. Kapoor, "Disaster in Rudraprayag District of Uttarakhand Himalaya: A Special Emphasis on Geomorphic Changes and Slope Instability,” Journal of Geography and Natural Disasters, Vol. 8, Issue 1, pp. 1-9, 2018.

[9] S. Khanduri, "Landslide Distribution and Damages during 2013 Deluge: A Case Study of Chamoli District, Uttarakhand," Journal of Geography and Natural Disasters, Vol. 8, Issue, 2, pp. 1-10, 2018.

[10] Sushil Khanduri, "Disaster Hit Pithoragarh District of Uttarakhand Himalaya: Causes and Implications," Journal of Geography and Natural Disasters, Vol. 7, pp. 1-5, 2017. 
Flash Flood struck Dhauliganga valley on February 7, 2021: A Case study of Chamoli district of Uttara...

[11] Sushil Khanduri, "Formation and Failure of Natural Dams in Uttarakhand Himalaya: An Observation from Lwarkha, Chamba Tahsil of Tehri Garhwal District, India," International Journal of Earth Sciences Knowledge and Applications, Vol. 3, pp. 12-22, 2021.

[12] K. S. Valdiya, "Damming rivers in the tectonically resurgent Uttarakhand Himalaya," Current Science, Vol. 106, No. 12, pp. 1658-1668, 2014.

[13] P. Rautela and R. K. Pande, "Non-monsoonal landslides in Uttaranchal Himalaya (India): Implications upon disaster mitigation strategy," Disaster Prevention and Management, Vol. 15, pp. 448 - 460, 2006.

[14] IS 1983, "Indian Standard (IS):1893, Part 1, Criteria for earthquake resistant design of structures,” Bureau of Indian Standards, New Delhi, 2002.

[15] J. R. Kayal, "Himalayan tectonic model and the great earthquakes: An appraisal; Geomatics," Natural Hazards and Risk, Vol. 1, pp. 51-67, 2010.

[16] A. Heim and A. Gansser, "Central Himalaya: geological observations of the Swiss expedition 1936,” Memoir Society Helvetica Science Nature, 73, pp. 1-245, 1939.

[17] K. S. Valdiya, "Geology of the Kumaun Lesser Himalaya,” Wadia Institute of Himalayan Geology, Dehra Dun, India. 249p, 1980.

[18] K. S. Valdiya, "Trans-Himadri intracrustal fault and basement upwarps south of IndusTsangpo Suture Zone," In Tectonics of Western Himalaya (eds. L.L. Malinconico and R.J. Lillie). Geological Society of America (Special Papers), Vol. 232, pp. 153-168, 1989.

[19] A. K. Jain, M. Shreshtha, P. Seth, L. Kanyal, R. Carosi, C. Montomoli, S. Iaccarino and P. K. Mukherjee, "The Higher Himalayan Crystallines, Alaknanda - Dhauli Ganga Valleys, Garhwal Himalaya, India," In (Eds.) Chiara Montomoli, Rodolfo Carosi, Rick Law, Sandeep Singh and Santa Man Rai, Geological field trips in the Himalaya, Karakoram and Tibet, Journal of the Virtual Explorer, Vol. 47, pp. 1- 38, 2014.

[20] D. Petley, "The catastrophic landslide and flood in Chamoli in Uttarakhand: the sequence of events," The Landslide Blog, AGU Blogosphere, blogs.agu.org/landslideblog/20, 2021.

[21] A. B. Shrestha, J. Steiner, S. Nepal, S. B. Maharjan, M. Jackson, G. Rasul and B. Bajracharya, "Understanding the Chamoli flood: Cause, process, impacts, and context of rapid infrastructure development," RIVER BASINS AND CRYOSPHERE, ICIMOD, Kathmandu, Nepal, 2021. 